London School of Economics \& Political Science WORKING PAPERS IN ECONOMIC HISTORY

\title{
FREEDOM AND GROWTH.
}

\section{THE EUROPEAN MIRACLE?}

S.R. Epstein

Number: 22/94

October 1994 



\title{
Working Paper No. 22/94
}

\section{Freedom and Growth. The European Miracle?}

\author{
S.R. Epstein
}

@S.R. Epstein,

October 1994

Economic History Department,

London School of Economics. 
S.R. Epstein

Department of Economic History

London School of Economics

Houghton Street

London WC2A $2 \mathrm{AE}$

United Kingdom

Phone: $\quad+44(0) 1719557046$

Fax: $\quad+44(0) 1719557730$

Additional copies of this working paper are available at a cost of $£ 2.50$. Cheques should be made payable to 'Department of Economic History, LSE' and sent to the Departmental Secretary at the address above. 


\section{FREEDOM AND GROWTH. THE EUROPEAN MIRACLE?}

Here the sweet odor of freedom greets me, that is, of the greatest constitutional limitation.

[Goethe in Augsburg, 1790 (Boyle 1992: 651)]

\section{Economic history and freedom}

This paper discusses the assumption, common to layman and economic historian alike, that political freedoms -- most notably the natural liberties established by the seventeenth-century civil wars in England -- were essential in ensuring Europe's breakthrough to the industrial world: in other words, in accomplishing the European miracle, as a distinguished former member of this School has dubbed it (Gellner 1988, echoing Jones 1981). This assumption I will dispute. I shall argue that most economic historians use the concept of freedom in a loose and misleading way, which hides more than it reveals. I shall, further, attempt to demonstrate that the connection between past political liberties and high rates of growth is unproven, and indeed that civic liberties may on occasion have been a cause of economic decline. I shall conclude by suggesting a different avenue of enquiry for understanding how political regimes may have affected growth in the past -- and are possibly doing so in the present also.

Before proceeding any further, however, we must briefly discuss how economic historians define freedom and how they apply the concept to their work. Most economic historians subscribe to the economists' normative definition of freedom as the ability of an individual to maximise her utility in the absence of constraints; it is a libertarian view that draws comfort from the claim, commonly ascribed to Adam Smith, that such a condition provides the most effective means of promoting both individual and general welfare. On closer scrutiny we see that the definition actually combines two distinct concepts of freedom: a broad and negative notion, which bears considerable social and institutional implications, of freedom from constraint, and a narrower and positive notion which refers to the ability to choose in the market. 
Historians concerned with economic growth tend, perhaps understandably, to be more interested in the former than the latter, more in questions of institutional change than in the nature of and the conditions for economic choice. What follows discusses some recent arguments which trace an explicit line of causation from forms of institutionalized freedom to economic growth in the past. The point of departure is the view that growth before the Industrial Revolution was primarily Smithian; that is, it was based on increasing division of labour (specialization) both within and between individual tasks and, more especially, within and between regions (e.g. Persson 1988). Since specialization is a function of the extent of the market, which in turn is defined mainly by the technical and institutional limits to trade, ${ }^{1}$ what we might call neoSmithian historians have paid particular attention to the historical barriers to the efficient allocation of resources and the free flow of goods.

In so far as market imperfections cause unequal access to economic resources, this approach brings the issue of freedom firmly onto centre stage. For if we accept that access to resources is sanctioned and reproduced by social norms and rules (property rights and rights of entitlement) that are defined and are thus potentially contestable in the political, rather than the purely economic realm, it follows (as the founders of the discipline, Hume, Smith, and Marx, were well aware of) that economic growth will be influenced to a considerable degree by the politically sanctioned distribution of political freedom -- and hence of power -- within societies.

It thus seems that the exercise of economic freedom is inextricably linked to the exercise of power. And yet, within the negative definition of freedom most often subscribed to by economic historians (that is, freedom from constraint), power and freedom stand opposed. For if we take the common definition of economic power as a person's ability to further her interests by imposing (or credibly threatening to

${ }^{1}$ Market size is a function also of individual demand and population size within a given territory, which however in pre-industrial societies tend to undergo change more slowly. 
impose) sanctions on another person where the converse is not true, ${ }^{2}$ it follows that freedom in the economic historian's sense is defined as the absence of such sanctions. In this sense, the relationship between power and freedom emerges as a zero-sum game: one can gain only as much freedom as someone else must lose power, and vice versa.

In actual fact the relation between freedom and power is far more ambivalent. On the one hand, while being free means to have the ability to achieve a desired goal, this ability in turn implies the active exercise of control. On the other hand, freedom can be defined only in relation to unfreedom; to be free there must be a condition one wishes to escape from. In both cases, freedom is based on an asymmetrical relation: freedom was born as a privilege and has remained so ever since (Bauman 1988: 9). Simply put, rather than following naturally from someone else's lack of power, a condition of freedom always implies the agent's exercise of power. ${ }^{3}$ In other words, the negative definition of freedom as the matter of what we are at liberty to do also implies a positive meaning of freedom as the matter of what we are able to do.

The purely negative definition of freedom we have just examined is partly the result of the economist's ingrained suspicion of arguments that appeal to normative concepts like power to explain the economic institutions of the past. ${ }^{4}$ Nonetheless, most

${ }^{2}$ A related voluntarist definition focuses on an agent's ability to affect the incentives facing another agent so that it is rational for the latter to do something she would not otherwise have chosen to do.

${ }^{3}$ This claim differs slightly from, but does not contradict, the more common statement that an agent's freedom involves exercising control over what happens to her.

${ }^{4}$ The suspicion is connected with the analytical distinction, established by the neo-classical agenda during the late nineteenth century, between the allocative and the redistributive functions of markets, i.e. between efficiency and equity -- neoclassical economics being concerned only with the former (de Marchi \& Morgan, forthcoming: Introduction). 
economists also have a strong ideological commitment to the view, purportedly bolstered by Adam Smith's attack on ancien régime and mercantilist restrictions, that the absence of political coercion is of essence for ensuring economic growth. ${ }^{5}$ This ambiguity with respect to the role of power in economic activities is the source of a curious paradox.

Following the principles of positive economics, hard-nosed historians have exercised considerable ingenuity and vast resources to demonstrate that the most extreme examples of past unfreedom, slavery, serfdom and debt bondage, were economically rational and efficient (Fogel \& Engermann 1974, Fenoaltea 1975, Engermann 1992). Most of us will find this conclusion disturbing, for at least two reasons. On the one hand, it implies that societies based on unfree labour would have been no better off had everyone been free. On the other hand, it seems to be unconcerned with freedom in the positive sense of a capacity or power to choose between different courses of action, of which human bondage is the most extreme denial. Our bemusement increases, however, when we are assured practically in the same breath that economic backwardness in the past was due largely to autocratic, absolutist lords who could exercise predatory rule over their lands -- on the converse assumption that the presence of negative freedom from constraint would have made everyone better off than they actually were. A by no means unique example of this tension can be found in a recent ambitious interpretation of the pre-industrial European economy (North \& Thomas 1973). Here we find chapter 3, which depicts medieval serfdom as a freely established contract between lord and peasant in which protection is exchanged for bonded labour, followed at a suitable distance by chapter 10 , which explains early modern Spanish and French economic retardation as the result of oppressive, and hence economically inefficient, political structures.

5 This view is based on a misguided projection of nineteenth- and twentiethcentury definitions of political freedom as universal suffrage and participatory democracy onto Smith's quite different political categories. (see Winch 1978: 83-6) 
The first kind of argument is clearly a dead end for our purposes, since it tells us little about the connection between freedom and economic growth, and indeed seems actually to deny that any such connection exists. Rather more promising is the opposite claim, customary to theories of modernization, that the presence or the development of political freedoms was a necessary condition for more rapid pre-industrial growth. ${ }^{6}$

\section{The European miracle}

In this context, the main line of thought brings under the same roof economic historians (e.g. North \& Thomas 1973) and historical sociologists (e.g. Hall 1985, Mann 1989) concerned with explaining the rise of the West. By the European miracle, as we saw, is meant the breakthrough to capitalist industrialism in late eighteenthcentury England, followed over the next few decades by the countries of continental Europe. Although the basic concept is hardly watertight -- a miracle, by definition, cannot be explained, and the assumption that an industrial breakthrough could have occurred only in western Europe is dubious to say the least (Jones 1988) -- explicit speculation about the links between Western institutional freedoms and European growth are unusual, and it is therefore worthwhile discussing them at some length.

North and Weingast (1989) have argued that the changes in the structure of political representation that followed the Glorious Revolution of 1688--89 had remarkable consequences for the eighteenth-century English economy. The story is a familiar one. The increasing tax needs of the Stuart sovereigns in the early seventeenth century could no longer be funded with traditional revenue from crown lands. Sale of these lands did not make up the shortfall, and the Stuarts were forced to find new sources

\footnotetext{
${ }^{6} \mathrm{I}$ follow economic historians' usual practice in confining myself to development in the narrow sense of an increase in per capita income. Were one to take a broader view of development that incorporates general measures of wellbeing such as basic civic and political freedoms, a democracy would virtually by definition be more conducive to development than a non-democratic regime. Such democratic freedoms are not, however, immediately apparent in the pre-industrial societies we are concerned with here, and so the issue can be safely ignored.
} 
of income. This set them against Parliament, which had the established right to grant new taxes, typically for extraordinary purposes such as war but also in the form of excise on trade. Faced with Parliamentary resistance, James I and especially Charles I imposed new taxes without the Commons' consent. They also resorted increasingly to forced loans (which were repaid, if ever, with considerable delay), to the sale of monopoly rights and of patents of nobility, to purveyance (the requisitioning of goods at below market prices), and to other more or less hidden forms of taxation. The more the landed and commercial interests represented in Parliament demanded conditions and limits to the Crown's authority in exchange for financial support, the more the Crown was forced by insolvency to resort to underhand expropriation.

The Stuart monarchy could act in this way because it combined executive, legislative and judicial powers and possessed a comparative advantage in coercion. Parliament's capacity to enforce institutional checks on royal power was restricted; consequently, the Crown could renege more or less unilaterally on prior agreements and modify the existing structure of property rights. The result was to promote a coalition of subjects seeking to preserve personal liberties, rights, and wealth; the Civil War ensued. None the less, the constitutional balance shifted decisively in support of secure property rights only with the Declaration of Rights of 1689 , which enshrined Parliamentary sovereignty. Parliament re-established authority over the right to tax, gained the right to audit government accounts, curtailed royal prerogative powers, and established the independence of the law. These political rights laid the foundations on which economic rights were erected.

North and Weingast measure the subsequent gains in economic freedom through changes in government finances and capital markets. Even though government expenditure and government debt increased hugely after 1688 (by 1720 public debt stood at over 50 times the level in 1688), rates of interest fell and the trap of inflationary finance was avoided; private capital markets also expanded under the wings of government finance, with beneficial effects on the wider economy. Greater 
financial efficiency was the result of the Glorious Revolution's enforcement of economic freedom in the shape of secure property rights. By making it impossible for the Crown to change the rules of economic activity ad libitum, Parliament also made the government's behaviour more predictable, and lenders were consequently forthcoming.

Examined more carefully, in fact, the latter argument is simply suggesting that secure property rights are a critical condition for growth. Secure property rights are not a critical measure of freedom, however, not even in the sense of equality before the law subscribed to by North and Weingast (Munzer 1990: ch. 7, Ryan 1987: ch.7). The latter's confusion arises from their conflation of freedom with the security of property rights engendered by a government's precommitment to constitutional rules:

For economic growth to occur the sovereign or government must not merely establish the relevant set of rights, but make a credible commitment to them. (North \& Weingast 1989: 803)

I return to this point further below. For the moment let us simply note that although an autocratic government (that is, one not subjected to constitutional checks and constraints) will be unable to provide the necessary commitment to existing property rights, and will therefore tend more or less deliberately to stifle opportunities for growth, it by no means follows that free (in the sense of Liberal democratic) ${ }^{7}$ institutions will produce an efficient or indeed superior degree of commitment. In fact, as we shall see, it is far from obvious that democratic freedoms will be associated either with secure property rights or with a credible precommitment to constitutional rules. Democratic freedoms do not by themselves provide the appropriate conditions for fostering economic growth.

${ }^{7}$ I follow this middle-of-the-road Liberal definition of democracy so as to avoid the complications that arise if one argues, as another former member of the School Friedrich von Hayek did, that a democracy may be illiberal and a dictator liberal (where liberalism is defined as a system of individual freedom under the rule of law with wide scope for free-market activity). (Arneson 1993: 145--6) 


\section{European cities and freedom}

The conviction none the less that the emergence of political and civil liberties was inextricably linked to economic freedom (North \& Weingast 1989: 829) ${ }^{8}$ also underlies the long-standing view that western Europe's successful path of growth owes much to the existence of independent cities (see Smith 1976: III, iii--iv). This proposition comes under two intertwined but separable forms. First, it is suggested that the economic and social changes linked to European modernization, that is, with the transition from a traditionalist, corporatist, religiously-minded society, to the increasingly secularised, individualistic and mobile world of capitalism, originated and developed in towns (Langton \& Höppe 1983, Hicks 1969). The growing material wealth, new codes of law, religious beliefs and aesthetics, nation states and, ultimately, world domination associated with western European modernization can all be traced back to the peculiar dynamism of its urban society, and to the social tensions and innovations that this engendered. Secondly, it is argued that European sovereigns were forced to meet their fiscal requirements by allying with the towns against the feudal aristocracy in exchange for financial support; in turn, bargaining over taxes led to forms of parliamentary representation and thus, over time, to modern parliamentary democracy.

In the first view, western European cities derive their unique historical role from being both the main and at times the only fora of exchange, and the main and at times the only centres of cultural, economic and institutional innovation. Within this brief, Max Weber is often credited with the opinion that the medieval Western city is the source of modern legal and political freedoms (Weber 1978: vol. 2, 1212--372, Käsler 1988:

${ }^{8}$ The lines of causation implied in the quotation and discussed in this essay run from political freedom to economic development. The opposite argument, that economic growth promotes political freedom, has been restated forcefully by Olson 1991; it is criticized by Huber, Rueschmeyer \& Stephens 1993. 
42--8, 200, Berman 1983: ch.12). ${ }^{9}$ But, as Weber pointed out, the origin of those freedoms lay in an act of usurpation of legitimate (feudal) power by groups of burgers who acted collectively to establish their free status -- that is, subject to a special and autonomous law (Weber 1978: vol. 2, 1254). The emergence of free citizen status, therefore, also defined non-citizens as unfree; urban freedom (similarly to North and Weingast's property rights) was the outcome of a juridically sanctioned privilege which distinguished the town from the feudal or subject countryside. Thus it hardly comes as a surprise that during much of the Middle Ages and the early modern period, 'freedom' was actually used in the sense of 'privilege' (Bridbury 1986).

This first line of argument therefore depicts town-country relations as a stark contrast between urban modernity and freedom and rural conservatism. Over the last twenty years, however, the evidence for these claims has come under strong and convincing attack. Research on pre-industrial rural manufactures (or proto-industry, as it is often called) shows not only that they had an often greater economic impact than had contemporary urban industries, but that a critical prerequisite for proto-industrial success was a lack of competing urban freedoms: an absence, that is, of those privileges that enabled a town to gain monopoly rents from its hinterland and ban any rural activities that threatened its own industries (Ogilvie 1993). Here, then, the ambivalent nature of political freedom raises a dilemma for those wishing to link such freedom to economic growth: urban privileges, which had been necessary to establish the towns' autonomy from feudal authority in the first place, later turned into fetters on growth and on the economic liberties of the rural population. The dilemma, of course, is the result of the asymmetrical relation between freedom and unfreedom that we discussed at the outset. 1323)

\footnotetext{
${ }^{9}$ Weber is actually rather ambiguous on this subject. (Weber 1978: vol. 2,
} 
A similar tension underlies our second model linking urban economic and political freedom, which centres on relations between cities and the state. This approach, although also owing something to Weberian analyses, emphasizes the capacity of preindustrial European cities to avoid the stifling embrace of the tax-hungry state: the dichotomy in this case being one between urban capital and state coercion. (Tilly 1990)

The relation between urban economic growth and political representation in late medieval and early modern Europe is discussed by Blockmans (1989), who postulates an inherent hostility between feudal and royal authority on the one hand and cities on the other. Monarchs regularly strived for total control of a territory from their administrative center, whereas cities were concerned with commercial profits and therefore preferred open routes of travel and communication along coasts and rivers to politically enforced borders. (Blockmans 1989: 733,735)

The main impetus to increased political coercion came from rising military competition between European states. The early modern military revolution had to be paid for by vastly increased rates of taxation. Being both wealthier and more easily assessed than the countryside, towns tended to bear the brunt of states' financial requirements. However, military expenditure and bureaucratic controls were antithetical to early commercial capitalism; therefore, where fiscal pressure could be exerted more or less unrestrained, commercial and financial metropoles were stifled. This explains why the core cities of the European economy were always fairly independent from overarching monarchies (Blockmans 1989: 752; see also Tilly 1990: 52--3); growth could occur only in towns or regions where state control was weak or non-existent, such as late medieval Barcelona, Prague, Augsburg, Nurnberg, Antwerp, Danzig and Flanders.

Urban commercial capital and state coercion are thus portrayed as antithetical. Political representation, however, saw monarchs and cities on the same side. The former required an ally to establish full sovereignty over the feudal aristocracy; in 
exchange for the towns' support, rulers vested them with vast political and economic privileges that transformed the urban elites into rentiers (Blockmans 1989: 752). This occurred in France, in the Crown of Aragon, in the southern Netherlands and in Piedmont. Towns free of a superior lord and left to their own devices, by contrast, eschewed representative institutions. Instead, either one metropolis established control over its region, as did Florence, Milan or Venice in central and northern Italy, or a loose federation of towns such as the North Sea Hanse emerged in its place. In the first case, the dominant city's elites were rapidly corrupted by their new-found powers, which they deployed to exploit their subject territories (Epstein 1993); in the second case, the federated cities suffered from a lack of organization and fell prey to more powerful territorial rulers.

Underlying this analysis is a paradox which seems to subvert any causal link between urban political and economic freedom. That is, just as economic freedom appears incapable of sustaining political freedom (in the shape of urban territorial independence), political freedom (in the shape of urban parliamentary representation) seems incapable of sustaining economic freedom. The rationale of this apparently pessimistic conclusion becomes clearer when we examine an example of city-state relations in greater detail.

The early modern Netherlands possessed both the most developed and urbanized European economy of their time and a precociously democratic government, a republican federation of 58 independent cities all having equal voting rights. They therefore seem to provide a good example for the claim that urban political freedom brought about economic success. Not so, argues Marjolene 't Hart (1989). When the Dutch constitutional settlement was developed in the late 1570 s, no individual city had as yet established superiority over the others. This lack of clear leadership was compounded by the rule that required the 58 cities' unanimity on all issues of national interest such as war, peace and taxation. Decision-making was thus a particularly complex and fraught process, prey to constantly shifting coalitions and to debilitating 
bargaining processes. Up to the Peace of Westphalia (1648), the all-out war of independence against the Spanish Empire provided the cities with a common external focus and helped them to paper over their differences. But the end of the conflict made compromise increasingly hard to achieve, and local particularism tended to prevail.

The dispersal of political authority among a large number of competing commercial and industrial centres restricted the late seventeenth-century Dutch state's capacity to make bold and timely decisions, particularly in matters concerning the country's commercial and political interests in the international arena. The need for unanimity made it harder to change and adapt to new international balances of power, which in turn became an important cause of Dutch decline in the eighteenth century (" $t$ Hart 1989: 681). In conclusion, although economic success achieved political freedom (by enabling the Dutch to finance an 80-year war of independence against the world's most powerful empire), the opposite seems not to have held true: in the longer run, political freedom may have been achieved at the cost of relative economic decline. As with the relations between town and country discussed above, we see how the political preconditions of urban economic success were later transformed into institutional fetters to further growth.

\section{Freedom and growth}

We appear to have come full circle. Having begun with the hypothesis that political freedom was essential for economic success, we are being led to conclude that the two may be incompatible. The modern version of this argument -- popular with Jacobins both Right and Left -- that democratic freedoms pose a threat to growth is based on two claims (Przeworski \& Limongi 1993). Firstly, democracies fall prey to pressure groups, whose elected representatives pursue the particularistic goals of their constituencies rather than collective or national interests; this tends to favour policies aiming at economic redistribution rather than generalized growth (Olson 1982, Becker 1983). And secondly, democracies can overturn past laws and decisions, so long as a qualified majority decides so and there exist no constitutional constraints on such 
change (Elster \& Slagstad 1988); this causes uncertainty and inhibits strategic planning and investment. The tyranny of particularism and the lack of precommitment therefore make it of the essence to insulate the state's decision-making processes in order to pursue effective policies for economic growth. Democratic inefficiencies mean that authoritarian rule is necessary to ensure long-term run growth.

The reader will recall that North and Weingast's analysis of the economic implications of English Parliamentary freedoms was criticized along similar lines. I pointed out that the authors confused the normative and political issue of freedom from autocratic government with the positive and economic issue of precommitment to rules, and I suggested that their assumption that democratic rule produces a higher degree of precommitment to rules than autocracy was unwarranted. The reasons for this scepticism are now clear: the need for precommitment is undermined by a democracy's ability to renege on past decisions and by its submission to the whims of particular interests.

Before concluding that economic growth and political freedoms are antithetical, however, let us return once more to North and Weingast's argument. At a closer reading, they imply a far greater degree of uncertainty than we might expect. In particular, they suggest that eighteenth century absolutist France may have been growing as fast as parliamentary England, thereby throwing into disarray their claim that institutional changes gave England a decisive economic edge over its European rivals, since the French regime was, of course, untouched by parliamentary reform before the Revolution.

The authors try to neutralize this potentially devastating admission (North \& Weingast 1989: 830) by suggesting that England's general economic success is demonstrated by its overwhelming military achievements during the eighteenth century, in particular against France: with the advantage of hindsight, we know that France was living on borrowed time. It is a bold sleight of hand based on the even bolder claim, that 
military success is proof of economic prowess. The claim is hardly borne out by the facts, however: as early modern Sweden and Brandenburg-Prussia demonstrated to great effect, one could be an outstandingly successful military state even while overseeing an impoverished and underdeveloped society.

This discrepancy between power and resources is actually rather easily explained: preindustrial success on the battlefield depended not on potentially available wealth, but on a state's ability to extract revenue efficiently from whatever its economy could offer (Brewer 1988: 336). Military effectiveness depended on administrative efficiency, not on a country's absolute level of wealth. This point has wide-ranging implications. For it has recently been argued that the most significant effects of the Glorious Revolution of 1688--89 lay precisely in the administrative changes which the event initiated, and which enhanced the English state's capacity to wage war: a period more famous for its praise of liberty actually witnessed the creation of the fiscalmilitary state (Brewer 1990: xi, xvii). Levels of taxation rose as high or higher than in the rest of Europe, and state debt reached unheard of proportions. Such changes became possible largely thanks to the reforms discussed by North and Weingast, which made government more publicly accountable and enhanced its political legitimacy. The changes also underlay a shift in England's international status, from the relatively marginal position it had held under the Tudors and Stuarts to its central role on the European and world stages after 1700 . The change was financed by taxation and sustained by war.

Although the incidence of English taxation resembled that of many other European states, the English system of exaction had a number of distinctive features. First, tax collection was more centralized than in rival states, and was based on larger numbers of centrally appointed and professionally trained government officials. Secondly, England's lack of internal jurisdictional and revenue boundaries made it easier to police and repress tax evasion compared to most continental countries, where jurisdictional fragmentation and administrative heterogeneity made revenue policing 
an administrative nightmare (Brewer 1988: 372). Thirdly, the English tax system applied uniformly throughout the country, again in striking contrast with rivals such as France and the Dutch Republic, where innumerable regional, group and individual privileges and immunities compounded the difficulty described above of ensuring fiscal compliance. Lastly, the openness of the English tax system to public scrutiny created a degree of public confidence that was lacking in other, more secretive countries, and conversely made it very difficult to voice opposition to taxes once Parliament had granted its consent. In sum, despite the English monarchy's constitutional constraints, the English tax system was both more efficient and less subject to evasion or resistance than under nominally more powerful, absolutist continental regimes.

This apparently paradoxical conclusion corresponds to recent re-evaluations of the character of ancien régime Europe, in particular of French absolutism. The currently accepted view of French absolute monarchy contrasts strikingly with the picture of a despotic and tyrannical regime outlined by North and others (North \& Thomas 1973: chs. 8, 10, North \& Weingast 1989, Macfarlane 1987, Olson 1991). If indeed one had to sum up the regime's failings in a single word, it would be: ineffectiveness. The main constraint on royal authority has already been mentioned: the towering pyramid of inherited and newly established powers and jurisdictions, which gave local and regional societies vast margins of political manoeuvre and, indeed, independence in their dealings with the crown. Within a society for which legal propriety was sacrosanct, the ruler could not, by law (and there were many different kinds of law with overlapping jurisdictions), encroach upon the privileges and rights -- the liberties, as they were rightly called -- of the provincial elites, the town councils, and the myriad other corporate bodies which made up the French body politic. Both in abstract theory and in everyday practice, the ruler was supreme political mediator rather than autocrat. (Mettam 1990)

This predicament had far-reaching consequences. The vast number of sectional interests endowed with juridically sanctioned liberties made it necessary to insulate the 
French royal councils from outside pressure by surrounding them with a high degree of secrecy; this in turn tended to transform law-making and especially economic regulation into a discretionary prerogative of the bureaucracy (Root 1991). Political secrecy and bureaucratic discretionality, which made it easier to lobby for privileges outside the glare of public scrutiny, are of course the alleged hallmarks of authoritarian absolutism. Yet the state's ability to implement its decisions, including grants of privileges and benefices, faced severe and in some ways insuperable constraints. Local and regional representative institutions (parlements, estates, urban councils and suchlike) could challenge the legitimacy of royal jurisdiction; the country's administrative complexity made uniform enforcement difficult if not impossible to achieve; and implementation itself was usually in the hands of local bodies, which had every opportunity to stall, delay or even boycott any centrally legislated decision.

In sum, despite the ostensibly greater authority of absolute monarchy, a French ruler was less powerful, that is, less able to put his will to good effect, than his English constitutional counterpart. Absolutist inefficiency was the result not of excessive and unchecked tyranny and of the lack of freedom, but of quite the opposite: of the surfeit of politically sanctioned liberties and of the difficulty in enforcing universally valid rules which those privileges entailed. By contrast, the English settlement of 1688--89 could work as effectively as it did because it relied on a powerful and centralized representative institution. Although the relative openness and size of the English assembly made it harder to reach decisions than in more secretive systems such as the French one, decisions taken and laws passed by the English Parliament had far greater legitimacy and could be implemented far more consistently and effectively than in continental absolutist states. (Levi 1988: ch. 6)

Thus, the main economic limit to absolutism seems to be one we saw imputed also to democracy: the excessive and debilitating hold of particular interests. Although the paradox should not be pushed too far (whereas Liberal democracy is based on 
universal equality before the law, ancien régime liberties were premised on legal inequality), it suggests an interesting conclusion with respect to our theme, the connection between political freedom and economic performance. Although the view that politics matters for economic growth seems intuitively correct, the nature of the political regime does not appear to be the critical explanatory variable: the republican Dutch faced similar problems of implementation to the absolutist French, and any advantages the English might have had seem to have had little to do with civic liberties as we conceive of them today. What we should perhaps be reflecting on instead are the institutions which mediate between the structure of political regimes and their economies: the mechanisms whereby political decisions are reached, and the administrative systems and written and tacit rules (including perhaps such intangible forces as trust (Gambetta 1988) and civic mindedness (Putnam 1993)) whereby such decisions are implemented. 


\section{References}

Arneson, R. J. 1993. Socialism as the extension of democracy. In Liberalism and the economic order, E. F. Paul, F. D. Miller Jr., J. Paul (eds), 145--71. Cambridge \& New York: Cambridge University Press.

Bauman, Z. 1988. Freedom. Milton Keynes: Open University Press.

Becker, G. S. 1983. A theory of competition among pressure groups for political influence. Quarterly Journal of Economics 98 (3), 371--400.

Berman, H. J. 1983. Law and revolution. The formation of the western legal tradition. Cambridge, Mass. \& London: Harvard University Press.

Boyle, N. 1992. Goethe. The poet and the age, I. The poetry of desire (1749--1790). Oxford: Oxford University Press.

Brewer, J. 1988. The English state and fiscal appropriation, 1688--1789. Politics and Society 16, 335--85.

Brewer, J. 1990. The sinews of power. War, money and the English state, 1688--1783. Cambridge, Mass.: Harvard University Press.

Bridbury, A. 1986. Markets and freedom in the Middle Ages. In The market in history, B. L. Anderson \& A. J. H. Latham (eds), 79--119. London: Croom Helm.

Elster, J. \& R. Slagstad (eds) 1988. Constitutionalism and democracy. Cambridge: Cambridge University Press.

Engerman, S. 1992. Coerced and free labor: property rights and the development of the labor force. Explorations in Economic History 29, 1--29.

Epstein, S. R. 1993. Town and country in late medieval Italy: economic and institutional aspects. Economic History Review 2nd ser. 46, 453--77.

Fenoaltea, S. 1975. Authority, efficiency, and agricultural organization in medieval England and beyond: A hypothesis. The Journal of Economic History 35, 693--718.

Fogel, R. \& S. Engerman 1974. Time on the cross: The economics of American Negro slavery. Boston: Little, Brown.

Gambetta, D. (ed.) 1988. Trust. Making and breaking cooperative relations. Oxford: Basil Blackwell. 
Gellner, E. 1988. Introduction. In Europe and the rise of capitalism, J. Baechler, J. A. Hall, M. A. Mann (eds), 1--6. Oxford: Basil Blackwell.

Hall, J. A. 1985. Powers and liberties. The causes and consequences of the rise of the West. Oxford: Basil Blackwell.

't Hart, M. 1989. Cities and statemaking in the Dutch Republic, 1580--1680. Theory and Society 18, 663--87.

Hicks, J. R. 1969. A theory of economic history. Oxford: Oxford University Press.

Jones, E. L. 1981. The European miracle. Cambridge: Cambridge University Press.

Jones, E. L. 1988. Growth recurring. Economic change in world history. Oxford: Oxford University Press.

Käsler, D. 1988. Max Weber. An introduction to his life and work. Oxford: Polity Press.

Langton, J. \& G. Höppe 1983. Town and country in the development of early modern Western Europe. Norwich: Institute of British Geographers.

Levi, M. 1988. Of rule and revenue. Berkeley \& Los Angeles: California University Press.

Macfarlane, A. 1987. The culture of capitalism. Oxford: Basil Blackwell.

Mann, M. 1989. European development: approaching a historical explanation. In Europe and the rise of capitalism, J. Baechler, J. A. Hall, M. A. Mann (eds), 6--19. Oxford: Basil Blackwell.

de Marchi, N. \& M. Morgan (eds) forthcoming 1994. Higgling: Transactors and their markets in the history of economics. Durham: Duke University Press.

Mettam, R. 1990. France. In Absolutism in seventeenth century Europe, J. Miller (ed.), 43--67. Houndmills: Macmillan.

Munzer, S. R. 1990. A theory of property. Cambridge: Cambridge Univesrity Press.

North, D. C. \& R. P. Thomas 1973. The rise of the western world. Cambridge: Cambridge University Press. 
North, D. C. \& B. Weingast 1989. Constitutions and commitment: evolution of institutions governing public choice in seventeenth-century England. Journal of Economic History 49, 803--32.

Ogilvie, S. 1993. Proto-industrialization in Europe. Continuity and Change 8, 159-79.

Olson, M. 1982. The rise and decline of nations. Economic growth, stagflation, and social rigidities. New Haven \& London: Yale University Press.

Olson, M. 1991. Autocracy, democracy and prosperity. In Strategy and choice, R.J.Zeckhauser (ed.), 131--57. Cambridge, Mass.: MIT Press.

Persson, K. G. 1988. Pre-industrial economic growth. Social organization and technological progress in Europe. Oxford: Basil Blackwell.

Przeworski, A. \& F. Limongi 1993. Political regimes and economic growth. Journal of Economic Perspectives 7 (3), 51--69.

Putnam, R. D. 1993. Making democracy work. Civic traditions in modern Italy. Princeton: Princeton University Press.

Smith, A. 1976. An inquiry into the nature and causes of the wealth of nations, E.Cannan (ed.) Chicago: Chicago University Press.

Tilly, C. 1990. Coercion, capital, and European states, AD990-1990. Oxford: Basil Blackwell.

Weber, M. 1978. Economy and society, 2 vols., G.Roth \& C.Wittich (eds). Berkeley, Los Angeles \& London: University of California Press.

Winch, D. 1978. Adam Smith's politics. An essay in historiographic revision. Cambridge: Cambridge University Press. 


\section{LONDON SCHOOL OF ECONOMICS}

\section{ECONOMIC HISTORY DEPARTMENT WORKING PAPERS}

1992

1. Competing Notions of "Competition" in Late-Nineteenth Century American Economics

Mary S. Morgan

2. New Light Through Old Windows: A New Perspective on the British Economy in the Second World War

Peter Howlett

3. Social Risk and Social Welfare in Britain, 1870-1939

Paul Johnson

4. Textile Factories, Tuberculosis and the Quality of Life in Industrializing Japan Janet Hunter

5. European Emigration 1815-1930. Looking at the Emigration Decision Again Dudley Baines

6. Scale Bias \& State Building: an Historical Perspective on Government Intervention, Political Systems \& Economic Performance in Tropical Africa Gareth Austin

7. Class Law in Victorian England Paul Johnson

8. The Instituto Nacional de Prevision Social and Social Insurance Reform in Argentina, 1944 to 1953

Peter Lloyd-Sherlock

9. Human Capital and Payment Systems in Britain, 1833-1914

Dudley Baines, Peter Howlett, Paul Johnson

10. Much Ado About Little

Robert Humphreys

11. Regional Fairs, Institutional Innovation and Economic Growth in Late Medieval Europe

S.R. Epstein 
12. The Performance of Public Enterprises in South Africa, Zambia and Zimbabwe during the last two decades

David Ferreira

13. Political Primacy in Economic Laws: A Comparison of British and American Anti-dumping Legislation, 1921

Peter M. Richards

14. Scientific Charity in Victorian London. Claims and Achievements of the Charity Organisation Society, 1869-1890

Robert Humphreys

15. Essex Men Vindicated: Output, Incomes and Investment in Agriculture, 1850-73

E.H. Hunt and S.J. Pam

1994

16. Learning by Doing among Victorian Farmworkers: A case study in the Biological and Cognitive Foundations of Skill Acquisition

David Mitch

17. "Blind Alley" Employment and the Role of Adolescent Labor Force Experience in Skill Development in Late 19th and Early 20th Century England David Mitch

18. British Imperialism in Microcosm: The Annexation of the Cocos (Keeling) Islands

Margaret Ackrill

19. Short-termism on Trial: An Empirical Approach Breht Feigh

20. Tenancy and Agricultural Techniques: Evidence from the 1882 Commission David Coombs

21. Economic Distress and Unemployment in Australia since 1850

Paul Johnson

22. Freedom and Growth. The European Miracle?

S.R. Epstein 

